\title{
Embedment of "Liquid" Capital into the Built Environment: The Case of REIT Investment in Hong Kong
}

\author{
Natacha Aveline-Dubach
}

\begin{abstract}
Since the Global Financial Crisis, the notion of securitization has become familiar to urban scholars, though research has been limited to mortgage-backed securities. This paper attempts to delineate the distinctive urban outcomes of securitization techniques applied to real estate, taking Hong Kong REITS (H-REITs) as a case study. It examines the way through which liquid H-REIT capital anchors into the built environment, and how this process impacts the life of local communities. The study shows that the urban dynamics of REIT investment contrast with the corporate environment and asset management objectives of the initiator/sponsor groups of H-REIT structures, a set of characteristics that are captured by the notion of "management styles." Amongst the three management styles identified in the paper, those developed by the Hong Kong family-based groups have not been sufficiently active to produce significant effects on the built environment. In contrast, the Link REIT has an aggressive value enhancement strategy that has reconfigured the social geographies of retail consumption across the whole territory, to the detriment of social housing estate residents. These results support the recognition that the financialization of the built environment tends to exacerbate social polarization and to trigger political conflicts, but they must be weighed against the contingent conditions in which real estate securitization take place.
\end{abstract}

KEYwORDs: Real estate; securitization; REITs; Hong Kong; property developers.

\footnotetext{
Natacha Aveline-Dubach is CNRS research director, affiliated to the laboratory Geographie-cités (University Paris I Panthéon-Sorbonne). Her recent work addresses the urban outcomes of the demographic transition and financialization of real estate, especially in Northeast Asia. She can be reached at $<$ aveline@jp.cnrs.fr >.
} 
Over the past two decades, institutional investment in property, once regarded as long-term and site-based, has become increasingly labile and disembodied due to a proliferation of real estate financial vehicles becoming tradable in the global market. To transcend the "spatial fixity" (Gotham, 2009) that is inherent to real estate assets, the structural reforms carried out in the finance industry have established a functional separation between property investment/ownership and the use of building facilities (Corpataux \& Crevoisier, 2005; Keogh, 1994). This has resulted in a circulation of increasingly mobile capital into built spaces, with international financial centers and major city regions as primary targets for capital accumulation (Attuyer, Guironnet, \& Halbert, 2012; Theurillat, Corpataux, \& Crevoisier, 2010).

Empirical research conducted by urban scholars has addressed structural changes in the built environment caused by the dynamics of real estate financialization. In focus are the mechanisms at work in new property development projects, seen as the "key space of confrontation between global marketplaces and local socio-economic demand" (Savini \& Aalbers, 2016). These authors have underscored the capacity of financial players to impose their selective investment criteria on the conception and design of urban projects. They have pointed out the role of the local state as a key agent for these transformations and highlighted the new mediatory function performed by property developers to translate investors' expectations and help sell them to local communities (Guironnet, Attuyer, \& Halbert, 2016; Theurillat \& Crevoisier, 2013). However, given the focus placed on property development, this scholarship has mainly addressed the strategies of unlisted real estate funds. Little attention has been paid to listed vehicles such as Real Estate Investment Trusts (REITs), which have limited involvement in development and rather specialize in property asset management.

REITs are investment entities comparable to mutual funds that pool capital from small and large investors to acquire and manage portfolios of income-producing properties of various categories, ranging from office and retail facilities to nursing homes. Usually traded on stock exchanges, REITs are the mainstream force of real estate securitization. Listed REITs account for approximately $2.5 \%$ of the stock markets and $5.5 \%$ of underlying assets worldwide. ${ }^{1}$ Nearly two-thirds of the global capitalization of REITs takes place in the US, where these instruments originated in 1960 (EY Global Real Estate, 2016, p. 4), but other large markets have recently developed in other continents, with Asia Pacific expected to undergo the most rapid growth of real estate securitization in the coming decades (Atchison \& Yeung, 2014).

\footnotetext{
${ }^{1}$ As of July 31, 2012. Retrieved from $<$ https://www.reit.com/Investing/GlobalRealEstateInvesting.aspx $>$.
} 
Since the Global Financial Crisis of 2007-2008, the notion of "securitization" has become familiar to urban scholars, though research has been limited to mortgagebacked securities. What characterizes securitization is the liquidity of capital. According to Gotham, a liquid asset can be defined as having "homogeneous, predictable and standardized features that enable financial actors to convert it into cash quickly and easily" (Gotham, 2009, p. 357). He states that the creation of "liquidity out of spatial fixity" operating through securitization is a source of conflicting interests that can lead to greater social inequality and generate political conflicts. Yet, empirical evidence remains to be provided on how securitization techniques applied to real estate affect the urban fabric and the lives of citizens.

This paper contributes to the discussion about the financialization of the urban by examining the way through which REIT capital anchors into the built environment, and how this process impacts the life of local communities. The research is empirically grounded in a case study of Hong Kong, where the development of REIT markets (referred to as H-REITs) has been marked by political and social controversy (Chan, 2003; Chung \& Ngai, 2007).

Like similar structures in the US and in East Asia, most H-REITs have been established by property firms, especially family-based ones, to spin off some of their assets onto REIT platforms. However, in the particular case of the H-REIT Link, the securitization process involved the privatization of a large-scale portfolio of 175 shopping centers and parking lots that were part of the welfare facilities in social housing estates. The Link REIT has consequently become one of the largest property owners in Hong Kong.

Given the range of contexts in which H-REIT structures have been established, one may expect subsequent varying dynamics in the investment of capital into built spaces. In this paper, I argue that the management styles of the trusts play a predominant role in these dynamics. I define the notion of management style as the combination of three interrelated elements: the corporate type of the originator group, the ownership structure, and the management policy of the underlying property assets.

To establish a typology of REIT management styles, I conducted semi-structural interviews with asset managers of the six H-REIT entities (out of 10) that operate in Hong Kong territory. The respondents were questioned about the underlying rationale for the establishment of the REIT, the place it has within the organizational structure of the initiator group, the REIT's capital ownership pattern, and its investment strategies and decision-making processes. Detailed information on REIT property portfolios was collected through websites and annual reports. Data collection also relied on in-depth interviews with financial experts from Hong Kong-based real estate consultancy firms, 
as well as a review of real estate reports and press articles. Based on the results of the first survey, I selected the Lok Fu Plaza shopping arcade as a case study to examine the effects of Link's “Asset Enhancement Initiatives" (AEI) on the working and living conditions of local communities. The shopkeepers of the shopping arcade were questioned about the evolution of their rental tenures, and business conditions following the refurbishment work. The residents were asked questions to find about the extent to which the renovation had modified their patterns of consumption of daily necessities. People over the age of 60 were targeted because they account for a growing percentage of Hong Kong's social housing estate residents and are the most vulnerable to changes in living conditions given their limited physical mobility and access to resources.

The paper is organized as follows: The first section discusses the relationship between market finance and built spaces with special reference to liquid capital, drawing from literature on territorial and financial economy. The second section sets the experience of H-REITs in the broader context of socio-political issues in Hong Kong, and develops the analytical framework. Finally, the last section describes the three management styles of H-REITs; it then examines the urban and social outcomes of Link's management strategy, taking the Lok Fu Plaza shopping mall as a case study.

\section{The Development of REITs within the Indirect Real Estate Investment Channel}

The past decades have seen a dramatic growth in institutional investment, reflecting the shift from a manufacture-driven economy to a finance-led economy (Aglietta, 2008; Boyer, 2000; Clark, 2000). This has resulted in a profound restructuring of property investment. In the past, real estate allocation by institutional investors — pension funds, mutual funds, and insurance companies - took the form of "brick and mortar" property assets on a long-term hold basis (Solnik \& McLeavey, 1991), but the reforms of the finance industry have introduced what Theurillat and Crevoisier (2013) call an "indirect channel of investment" (Figure 1) that has turned real estate into a quasi-financial asset (Coakley, 1994). As a result, real estate has seen its investable universe grow dramatically (Newell \& Worzala, 1995) and its tradability further enhanced by information and communication technologies (Lizieri \& Finlay, 1995).

By gaining a global reach, the indirect channel is expected to strengthen the diversification power of real estate (Baum \& Hartzell, 2012). The underlying rationale is Markowitz's portfolio theory (Markowitz, 1952), which places great emphasis on the correlation of returns between various asset classes. Because real estate has a 


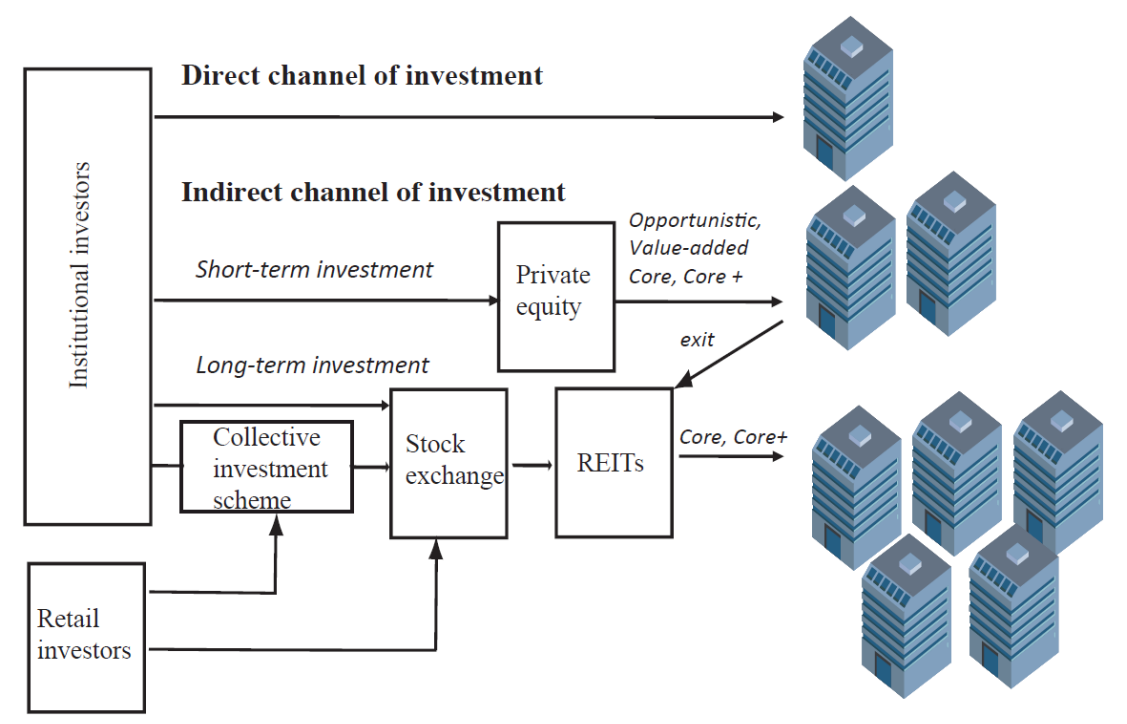

Figure 1. The circuits of capital for real estate investment.

Sources: The author, based on Theurillat and Crevoisier (2013).

traditionally low return correlation with bonds and stocks, it is recognized that adding property assets to a multi-asset financial portfolio is likely to reduce risk and consequently enhance the overall performance of the portfolio (Sirmans \& Worzala, 2003). Global investment is then aimed at increasing the benefit in diversifying real estate by giving access to a wide range of property markets subject to differentiated growth cycles - in both geographical and sectoral terms, with the possibility of achieving higher returns in emerging markets (Falzon, Halle, \& McLemore, 2003; Newell \& Worzala, 1995).

In addition to diversification, indirect real estate investment offers greater flexibility in financial portfolio management. It lowers the risk of immobilization of capital (Corpataux \& Crevoisier, 2005) and allows the management of real estate assets to be outsourced to specialized service providers (Boisnier, 2015). Institutional investors have thus shifted their capital allocation towards indirect real estate on a massive scale. Indirect investment operates through two main vehicles: (1) private equity (unlisted funds) with typical holding periods of four to six years, and (2) liquid REITs investing on a long-term basis ${ }^{2}$ (see Table 1). While the former accounts for more than half of available capital targeting real estate (56\% of US $\$ 443$ billion raised globally in 2015)

\footnotetext{
${ }^{2}$ I do not take into account the shares of listed property groups, given the high diversification of their businesses, beyond real estate investment and management.
} 
ISSUES \& STUDIES

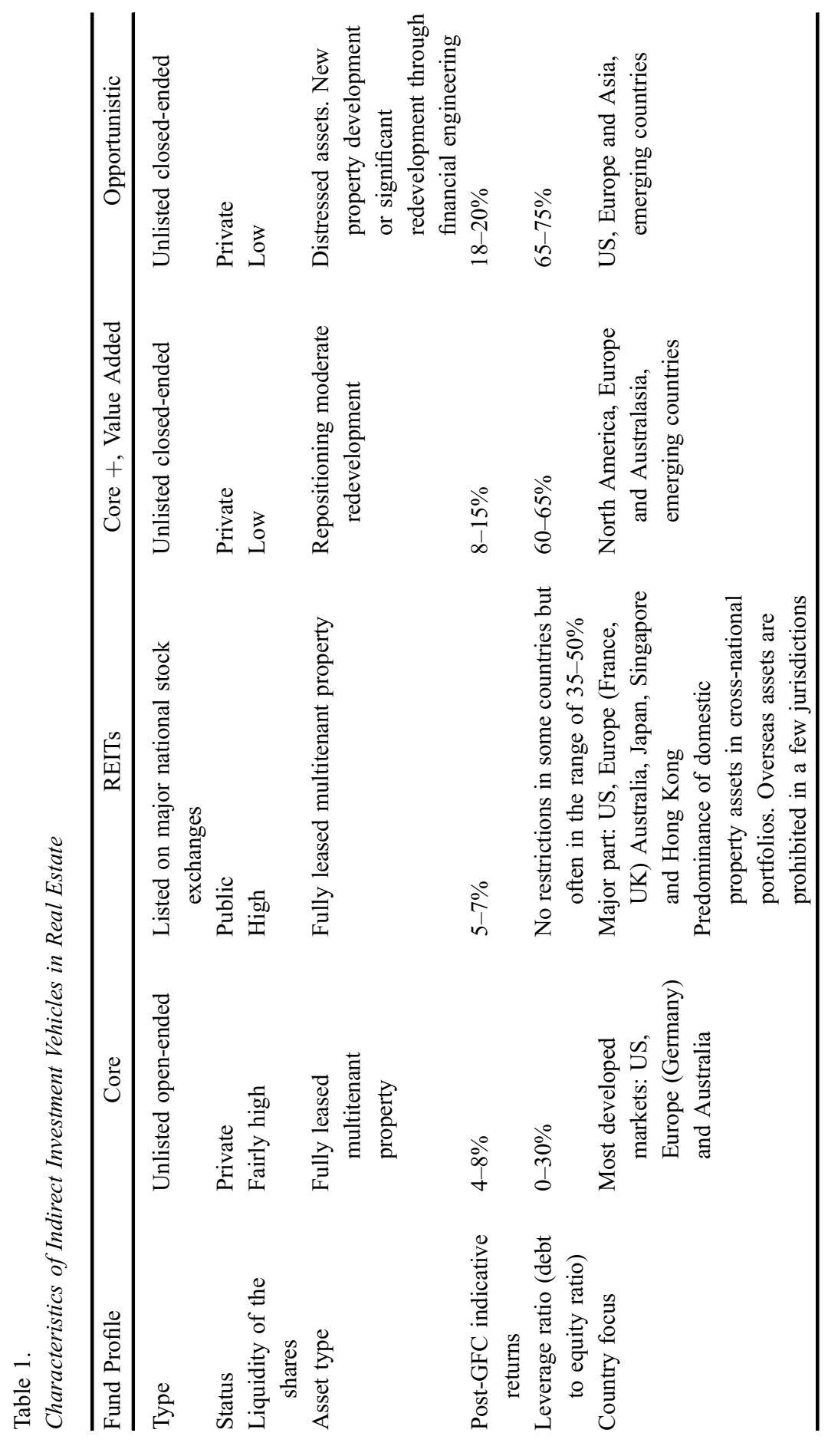




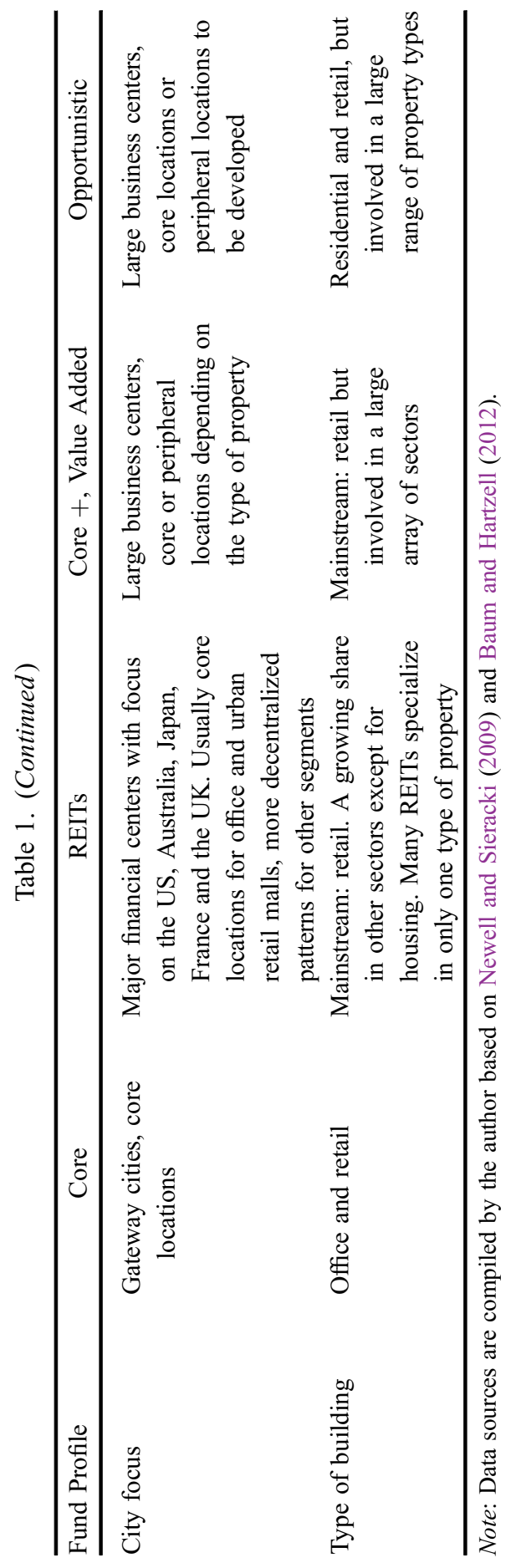


(Cushman \& Wakefield, 2016), showing virtually no limit in terms of geographic or asset type allocation, the latter contributes to approximately $6 \%$ of the new capital raised, focusing on high-grade properties primarily located in major financial centers. At the time of writing, the global capitalization of REITs has reached US\$1.7 trillion (Cushman \& Wakefield, 2016, p. 4). Given the prime location of their assets, REITs provide stable but moderate returns, and are thus at the lower end of the risk-return spectrum. They belong to the low-risk "core"/“core+" category, in contrast with unlisted funds which, despite encompassing the whole spectrum of risk-return profiles, tend to focus on the top of the risk ladder with highly rewarding "opportunistic" strategies.

\section{The Growing Quest for Liquidity in Real Estate Investment}

While institutional investors show a marked preference for unlisted funds, they tend to be increasingly lured by REITs. Reasons for this include REIT regulations and the characteristics of real estate securitized markets. REITs are required to distribute their earnings through regular dividend pay-outs and can deduct these dividends and avoid most or all tax liabilities, which make them a favorite for income-seeking investors (Newell, 2011). Their limited bank borrowing powers (low leverage ratio in most jurisdictions), associated with stable cash flows, give them "defensive" characteristics compatible with risk-adverse strategies. Adding to this, the liquidity of the real estate securitization channel has been enhanced and made effective by large trading volumes, owing to the widespread adoption of REIT regulations, especially in the past decade (36 countries in 2016). In addition, investors' confidence in securitized real estate has been further increased in recent times by the resilience of REIT markets to the global financial crisis (Sotelo \& McGreal, 2013). In the case of the US REITs, Wechsler (2013, p. 44) reports that equity REITs delivered an average annual total return of $9.24 \%$ in the period 2008-2012, compared to $4.53 \%$ from the S\&P 500 .

The quest for liquid real estate is further enhanced by a longer life expectancy in developed economies. Pension funds are facing a dramatic increase in retirees from the baby boom generation (Dixon \& Monk, 2009), which causes a mismatch in the ratio between pension contributors and beneficiaries. These risk-averse investors need to allocate a greater share of capital to the stock markets in order to strike a new balance between risks and returns (Engelen, 2003). Yet the most rapidly expanding demand for securitized real estate is likely to arise from Asian pension funds. These players are currently experiencing an explosion in growth as a result of rapid aging and residual welfare provisions, and are demonstrating a strong interest in future REIT allocation as suggested in a recent survey conducted by the Asia Pacific Real Estate Association (APREA, 2014). 
Aging also enhances the need for short-term saving instruments by small investors. Middle-class households, being exhorted in liberal welfare states to behave as "investor subjects" (Langley, 2007; Martin, 2002) are increasingly in search of financial vehicles for precautionary savings (Pierson, 2002). REIT securities give them access at low entry cost to property exposure, in contrast with private equity restricted to corporate investors and high net-worth individuals with investment shares over US\$5 million. Access to REIT markets is generally mediated by collective investment schemes managed by financial intermediaries and institutional investors (French, Leyshon, \& Wainwright, 2011). Thus, the massification of household savings vehicles, or the "coupon pool" (Froud, Haslam, Johal, \& Williams, 2002), controlled by increasingly global and influential players, acts as a driving force for the development of the real estate securitization channel.

\section{Property Developers and the Anchorage of Liquid Capital into the Built Environment}

In the face of this escalating demand for short-term, flexible vehicles rooted into the urban fabric, real estate industries are being compelled to develop adaptive strategies. As stressed by Wood (2004), property markets are embedded in institutional frameworks where situated knowledge and political influence predominate. Thus, local real estate players, especially development firms, have the power to facilitate - or, conversely, to impede (David \& Halbert, 2014) — the penetration of finance capital into built spaces. Theurillat and Crevoisier (2013) have coined the term "anchoring process" (of capital) to describe how developers perform new forms of negotiation with a range of actors involved in urban projects to translate the expectations of financial investors (in terms of risk and return) into elements of the urban fabric. In emerging countries marked by unclear land titles and intricate bureaucracies, the anchoring process may involve a web of players in the form of "transcalar territorial networks" to mitigate the risk perceived by foreign investors (Halbert \& Rouanet, 2014).

The establishment of real estate securitization channels brings a new dimension to the compliance of real estate industries to financial norms. Property players must first and foremost enculturate the underlying rationale of securitization, a concept that originated in the US four decades ago (Kendall \& Fishman, 2000). Wainwright (2009) gives an account of the problematic embedment of US residential mortgage securitization (RMBS) into the UK's finance industry in the $1990 \mathrm{~s}$, and stresses the various issues - especially with respect to legal, accountancy and computing aspects - that British financial players had to address. Real estate securitization further ingrains the Anglo-American financial investment paradigm in real estate, which focuses on rental 
yields associated with market value as an accounting reference (viewed as the permanently evolving product of future income streams through discounted cash flows), while many countries traditionally approached real estate investment through a patrimonial or capital gain perspective, often based on the historical book value. This shift requires sophisticated computer-based appraisal models that may seriously challenge recipient real estate industries (Aveline-Dubach, 2014).

Securitization also bridges financial and development functions in the real estate industry, giving rise to new business segments. Among these, the asset manager plays a prominent role in the fixation of REIT capital in built objects. REIT asset management can be operated internally by officers and company personnel hired by the REIT, or externally through a management contract with a fee based on assets or property income or a combination of both. Because external management involves the separation of ownership and control, it has the potential to generate conflicts of interest between unit holders and managers. A study on a US-based REIT by Capozza and Seguin (2000) finds that the strategy of asset investment significantly differs between external versus internal management, the former being less performant than the latter.

Investment policy is also influenced by the structure of corporate ownership. In the case of family-controlled firms, the risk is high that family members might act in their own interest at the expense of minority shareholders (Claessens, Djankov, \& Lang, 2000; Ng, 2005). A higher degree of control by a single shareholder may thus determine "unexpected" asset management strategies. In East Asian countries, REITs cumulate external management structures and family-controlled ownership, which makes them particularly prone to agency issues (Pica, 2011). The management structure is usually a wholly owned subsidiary of a family-based property developer called a "sponsor group" (Ooi \& Har, 2009). This places East Asian property developers in a strong position to divest their properties into one or several REIT platforms, in order to unlock the value of their real estate portfolios and redeploy capital into (re) development, while receiving fee-based income from their securitized properties (Ooi, Ong, \& Neo, 2011). However, family-based groups may not follow expansive strategies if these are not aligned with their interests.

\section{Neoliberal States and Negative Social Externalities of Financialization}

Whatever the degree of involvement by local property players, securitized real estate channels could not have been developed without strong support from the state. Indeed, adopting securitization techniques requires a particularly pro-active initiative by the state. It implies the provision of a supportive environment for foreign and 
domestic investment, the creation of dedicated legal and regulatory frameworks, the provision of transparent information and the imposition of standardized methods of performance assessment (Martin, 2002; Newman, 2009). In the case of real estate securitization (as compared to mortgage securitization), the granting of tax privileges additionally involves political trade-offs in the distribution of public spending (Boisnier, 2015). Such initiatives are being taken under the influence of pervasive and multifaceted neoliberalism (Brenner \& Theodore, 2002, 2005; Swyngedouw, 2004), propagated and often imposed by international institutions (Theodore, Peck, \& Brenner, 2011).

At the local level, these actions are generally backed up by cash-starved public authorities that seek greater capital mobility to catalyze endogenous economic growth and enhance urban competitivity (Brenner \& Theodore, 2002; Le Galès, 2000). As holders of a range of legal and financial resources, local states can influence the profitability of property investment (Halbert \& Attuyer, 2016). They develop or facilitate arrangements involving finance capital to conduct so-called strategies of "creative destruction" (Brenner \& Theodore, 2002) whereby existing non-market space and traditional working-class neighborhoods are converted into new privatized space for corporate and elite groups. To balance public budgets, welfare facilities are also being increasingly privatized through large package deals to financial players. Fields and Uffer (2016) have documented the effect of en bloc sales of social housing blocks on the living conditions of local residents in the case of New York and Berlin. They highlight the spatial strategies conducted by private equity investors to upgrade the assets in areas of greater housing demand, and show how this has resulted in the physical and social deterioration of other neighborhoods, resulting in a growing isolation of low-income tenants. This did not happen without contestation since, as evidenced by Fields (2015), the mobilization of New York community organizations forced elected officials and financial institutions to recognize and take action on the problem. In Hong Kong, the privatization of welfare facilities through real estate securitization concerned shopping centers and not housing blocks, but the strategies pursued by financial investors bear some similarity to those observed in New York and Berlin. The next section will address this experience.

\section{The (Under) Development of REIT Markets in Hong Kong}

\section{Hong Kong, A Paradise of Securitization}

Unlike China or India, where the securitization of real estate presents a challenge, Hong Kong meets all the criteria needed for a REIT market to flourish. Considered a 
"global city" by a number of researchers (Chiu \& Lui, 2009; Meyer, 2000; Sassen, 2002), Hong Kong ranks at the top of Asia's list of financial centers and is the third largest in the world according to the Global Financial Center Index, ${ }^{3}$ with a stock exchange that operates as a major fund-raising platform for Mainland enterprises (Lai, 2012; Zhao, Lao, \& Neo, 2013). It also stands as one of the most securitizationfriendly jurisdictions in Asia (Chow, 2011), owing to a sophisticated regulatory framework based on English law combined with low taxation duties.

Adding to financial skills and investment-friendly legal and regulatory rules, Hong Kong has a sophisticated commercial real estate market dominated by worldclass domestic players. Property development groups account for $23 \%$ of the capitalization of listed property groups worldwide (Newell, Wu, Chau, \& Wong, 2010, p. 193). Owned by a handful of powerful families, they have grown into conglomerates since 1997, by taking over or merging with declining British companies (Chiu \& Lui, 2009) and expanding their investments in Mainland China (Poon, 2010). Due to the extensive business diversification of these conglomerates, their securities traded on Hong Kong stock exchange do not provide attractive returns (Studwell, 2008). Therefore, when REIT markets took root in Hong Kong in 2005, there was a strong local demand for investment vehicles offering regular dividend yields from income-producing properties. This demand was further driven by an increasing need for precautionary savings by a rapidly aging population, in a context of residual welfare for healthcare and pension provision (Chan, 2003; Chow, 1998; Lee, 2005). Yet the H-REIT did not fully meet the expected success, due to various blockages from the supply side.

\section{The Controversial Birth of H-REITs}

The project to establish REIT markets in Hong Kong took place a few years after the handover of the territory to China and the onset of the Asian financial crisis. Policy makers responded to the recession by attempting to turn Hong Kong into a global financial center (Chiu \& Lui, 2009). The privatization of public assets was viewed as a key measure to boost private confidence by alleviating public expenditure. As part of this policy, the government added to the agenda the privatization of retail properties and car parks in 175 social housing estates scattered across the whole territory. Hong Kong's large-scale subsidized rental housing, regarded as "charity" rather than welfare by policy makers (Chung \& Ngai, 2007), is a legacy of the colonial rulers' strategy to

\footnotetext{
${ }^{3}$ Published by the Z/Yen Group, the Global Financial Centers Index (GFCI) ranks the competitiveness of financial centers based on a set of indices covering five areas: "business environment," "financial sector development," "infrastructure factors," "human capital," "reputation and general factors."
} 
prevent social unrest and secure a cheap labor force (Chiu, 2007). Run predominantly by the Hong Kong Housing Authority (HKHA), it accommodates 30\% of the population. Given the large number of assets to privatize, it was decided to adopt REIT regulations and transfer the properties to a listed company backed by a consortium of financial institutions including the firm Goldman Sachs, HSBC and the UBS Investment Bank. The newly established REIT entity, the Link, had to meet statutory requirements of fulfilling the daily needs of public housing residents in accordance with the Housing Ordinance (Chiu, 2010). In 2004, the Link carried out an initial public offering that was very successful and turned out to be the biggest REIT deal of the year globally, with orders equaling 28 times the amount of stock on offer. ${ }^{4}$

To gain political acceptance of this project, the government advertised the use of a REIT structure as "a way to return the wealth to the people" (Chung \& Ngai, 2007, p. 79), with the explicit assumption that every citizen could become a stockholder. However, only those households from the middle and upper strata could afford to invest in financial markets. For local residents, especially HKHA's older housing tenants living on welfare, the privatization of retail facilities threatened to affect their livelihood (around one fifth of them receive a monthly allowance of less than US $\$ 460^{5}$ ). Therefore an aged resident, backed by politicians, took legal action, accusing the HKHA of breaching the Housing Ordinance. In 2005, the Court decided that the HKHA was at liberty to sell its commercial and car park properties, but made it clear that the company should continue to provide appropriate retail amenities to its housing tenants.

\section{The Mixed Success of Real Estate Securitization in Hong Kong}

Following the decision of the Court, the Link was listed in November 2005, inaugurating the launching of real estate securitization in Hong Kong. After the Link, nine other REITs were listed at the Hong Kong stock exchange. However, the growth of securitized real estate did not meet the investors' expectations. More than one decade after the first IPO, the market is still dominated by the Link, which absorbs $53 \%$ of the H-REIT capitalization (Table 2).

Currently, the H-REIT market ranks third in Asia, after Japan and Singapore in terms of capitalization. With only 10 REIT structures, Hong Kong pales in comparison to Singapore (30) and Tokyo (43). Of the 13 Hong Kong property development and

\footnotetext{
${ }^{4}$ Los Angeles Times, December 20, 2004.

${ }^{5}$ China Morning Post, May 22, 2012.
} 


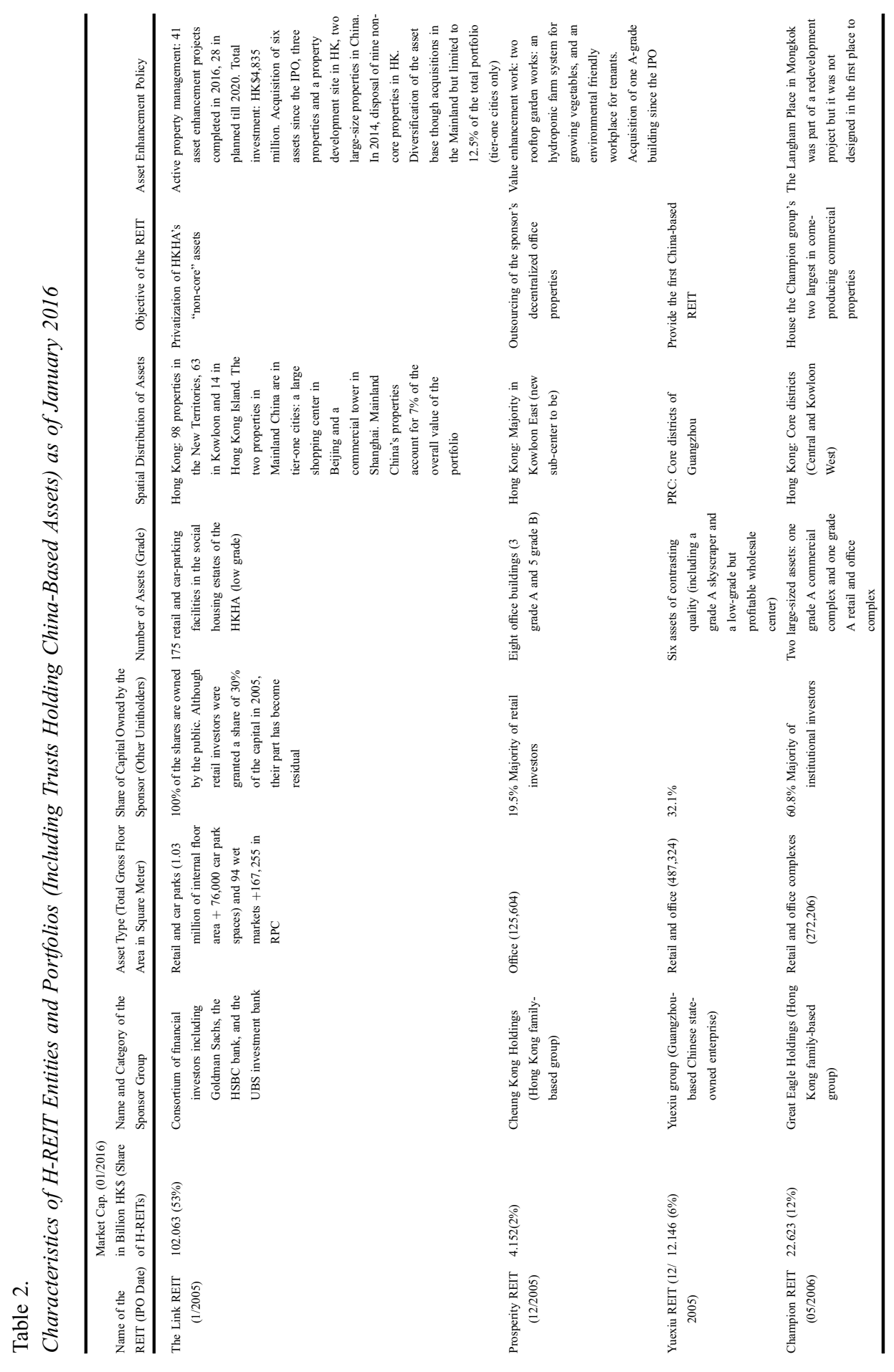




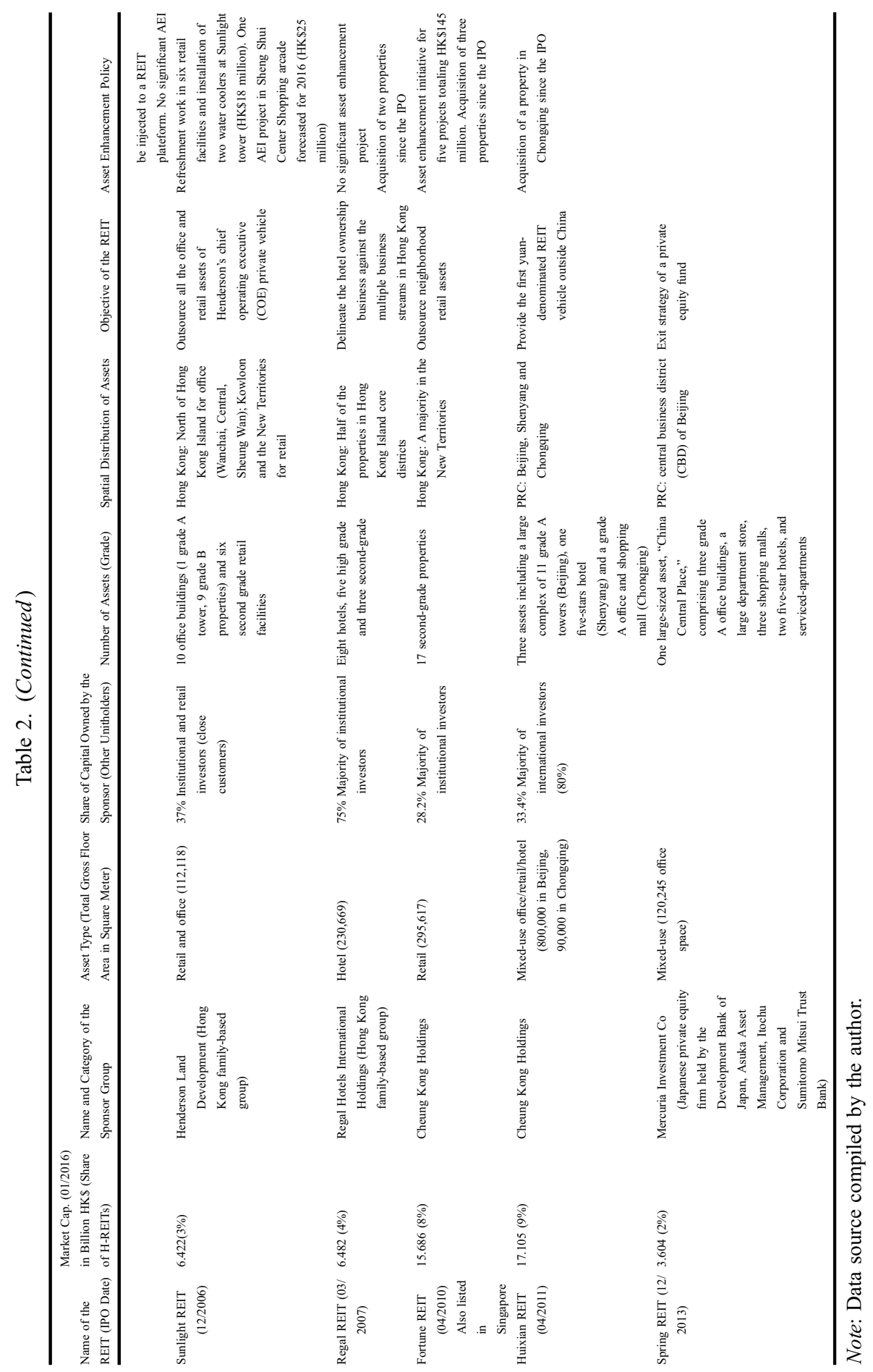


investment conglomerates, only three have established REIT funds, of which the Cheung Kong group, headed by the tycoon Sir Ka-shing Li, is the most active with three trusts, accounting for one-fifth of the total capitalization of H-REITs.

Given Hong Kong's status as a gateway to China, the H-REITs were geared towards substantial cross-border investments in the Mainland (Newell et al., 2010). Yet China-based property portfolios today only account for a mere $18 \%$ of the market capitalization of H-REITs. Although Hong Kong family-based conglomerates hold significant ownership of sophisticated and well-managed commercial properties in China's major cities (Heung \& Zweig, 2011), only one group has established a Chinabased REIT (Huixian REIT, run by Cheung Kong Holdings). It is a fact that China's state maintains strict rules to limit transnational investment into its domestic property, especially through financial investment vehicles (Aveline-Dubach, forthcoming). But that did not stop nine Singaporean property groups from developing China-based REIT portfolios with considerable diversification by property type (industrial, retail, logistics, office, hotel and resort), and geographic area $\left(12\right.$ cities $\left.^{6}\right)$. Non-domestic players have nonetheless used the Hong Kong stock exchange as a platform to develop China-based REIT asset portfolios. The Chinese state-owned enterprise Yuexiu based in Guangzhou has injected six assets into an H-REIT, and two equity firms (the Japanese firm Mercure and the US-based Carlyle PERE) have established new $\mathrm{H}$ REIT portfolios in the hotel and office sectors.

The relative underdevelopment of H-REITs is generally explained by the high level of property values in Hong Kong and the lack of tax privileges in H-REIT regulations $^{7}$ (Chow, 2011). However, these arguments do not take into account the highly uneven market structure of H-REITs. To gain an understanding of these distinctive characteristics, it is necessary to examine the positioning of the various real estate players towards the securitized channel.

\section{Research Framework}

This subsection sets out to identify key elements of differentiation in the way liquid capital penetrates built spaces through REIT vehicles, and how it impacts the built environment. As documented by financial economists, investment strategies by

\footnotetext{
${ }^{6}$ An overwhelming share of properties nonetheless focus on Shanghai and, to a lesser extent, Beijing. Some trusts run a pan-Asian portfolio with only one or two properties in China.

${ }^{7}$ Unlike most other REITs, H-REITs do not enjoy corporate tax breaks since dividend payments are taxfree in Hong Kong. Therefore, there is no apparent tax incentive for property companies to turn themselves into REITs.
} 
property asset managers differ between corporate governance and related capital structure. Building on these findings, I elaborate on the notion of "management style" to establish a typology of H-REITs that captures the transformation of built objects in connection with the attributes of the trusts. The notion of management style combines three key characteristics: the corporate type of the originator group of the REIT entity, the ownership structure of the REITs, and the management policy of the underlying assets.

A vast majority of REITs in East Asian countries is formed by property-holding groups, or so-called "sponsor groups," that spin off part of their assets onto REIT platforms and keep control over their management through an external structure. This control is further enhanced by pyramid structures and cross-holdings among firms that characterizes East Asian countries (Claessens et al., 2000). The resulting separation of ownership and control increases the risk that the manager/sponsor might act in its own interest at the expense of other shareholders. Yet the modes of external management differ across Asia according to the type of the sponsor group. In Japan, property groups are generally bank-based, while in Singapore they are controlled by a mixture of family and government ownership (Ng, 2005). In contrast, as mentioned earlier, Hong Kong property groups are predominantly family-based (Poon, 2010), which exacerbates the potential conflicts of interests. Thus, corporate governance differs across REIT structures, depending on whether they are controlled by families, financial or state entities.

Control by the sponsor group is also regulated by the ownership structure of the REIT. A large holding of capital by the sponsor group reflects its reluctance to outsource properties and its strategy to capture most of the underlying income streams of the REIT platform. Conversely, a low share indicates that the sponsor is willing to embrace an asset-light model. Another important aspect of the capital structure is the respective share allocated to institutional and "retail" (individual) investors. Considering that REITs offer a rare opportunity for small investors to access real estate investment at low entry cost, the institutional/retail capital ownership balance indicates the extent to which property income and value is shared with household savers.

Benefits drawn from the property portfolios differ across REIT structures depending on the investment and management strategy of the underlying assets. REITs are expected to invest in quality-grade assets in prime locations so as to provide stable dividend payouts to shareholders and secure a "dynamic" management with easy-tosell properties. In fact, it appears that the formation of REIT asset portfolios is highly contingent on investment opportunities, as evidenced in Hong Kong by the Link's experience. Agency problems may also arise, especially in family-controlled groups, 
where the sponsor group can be incited to divest second-grade properties. With regard to the urban dynamics of investment strategies, however, their focus is more on the property's potential for transformation than on its quality. The securitization process does not automatically lead to a change in the built space, which can only occur when the asset manager undertakes a value enhancement of the portfolio by changing the tenant-mix or the tenant occupancy agreement of the properties, or after the refurbishment of existing buildings or the development of new ones. There is thus a wide scope for asset management strategies along the passive/active continuum.

\section{The Three Management Styles of H-REITs Structures}

The study has identified three distinct H-REIT management styles, which I designate as follows: accounting, divesting, and value addition (see Table 3).

\section{Passive Management Styles of Hong Kong Family-Based Groups}

The "accounting" management style is characterized by a large majority of capital held by the sponsor group (60-75\%), with the remaining fraction owned by institutional investors. It involves two brothers from the same family, who run the investment-driven Eagle Holdings Group and the Regal Hotel Group, respectively. Both sponsors have outsourced their assets primarily for accounting purposes, in order to delineate income producing assets (Champion) or hotel business (Regal) from other activities. The properties are of high quality (A-grade buildings or equivalent), located in prime or strategic locations for hotel business, and rented to blue chip companies. There has been no expansion of the portfolios since the initial public offering (IPO).

In contrast, although also involving powerful family-based groups in Hong Kong, but of a different type (development-driven), the "divesting" management style involves a low share held by the sponsor group, amounting to $20-30 \%$ of the capital. The remaining portion is generally owned by a majority of institutional investors. This category of trust has been established by the conglomerates Cheung Kong and Henderson. Their portfolios hold a majority of second-grade buildings (neighborhood shopping arcades and B-grade office buildings with industrial tenants) in non-core areas served by the MTR (New Territories) or in the immediate vicinity of core business zones (future Kowloon East sub-center, Sheung Wang in Hong Kong Island). Likewise, the expansion of the portfolios has been very modest with two or three new acquisitions at best over more than five years. Some properties have undergone 


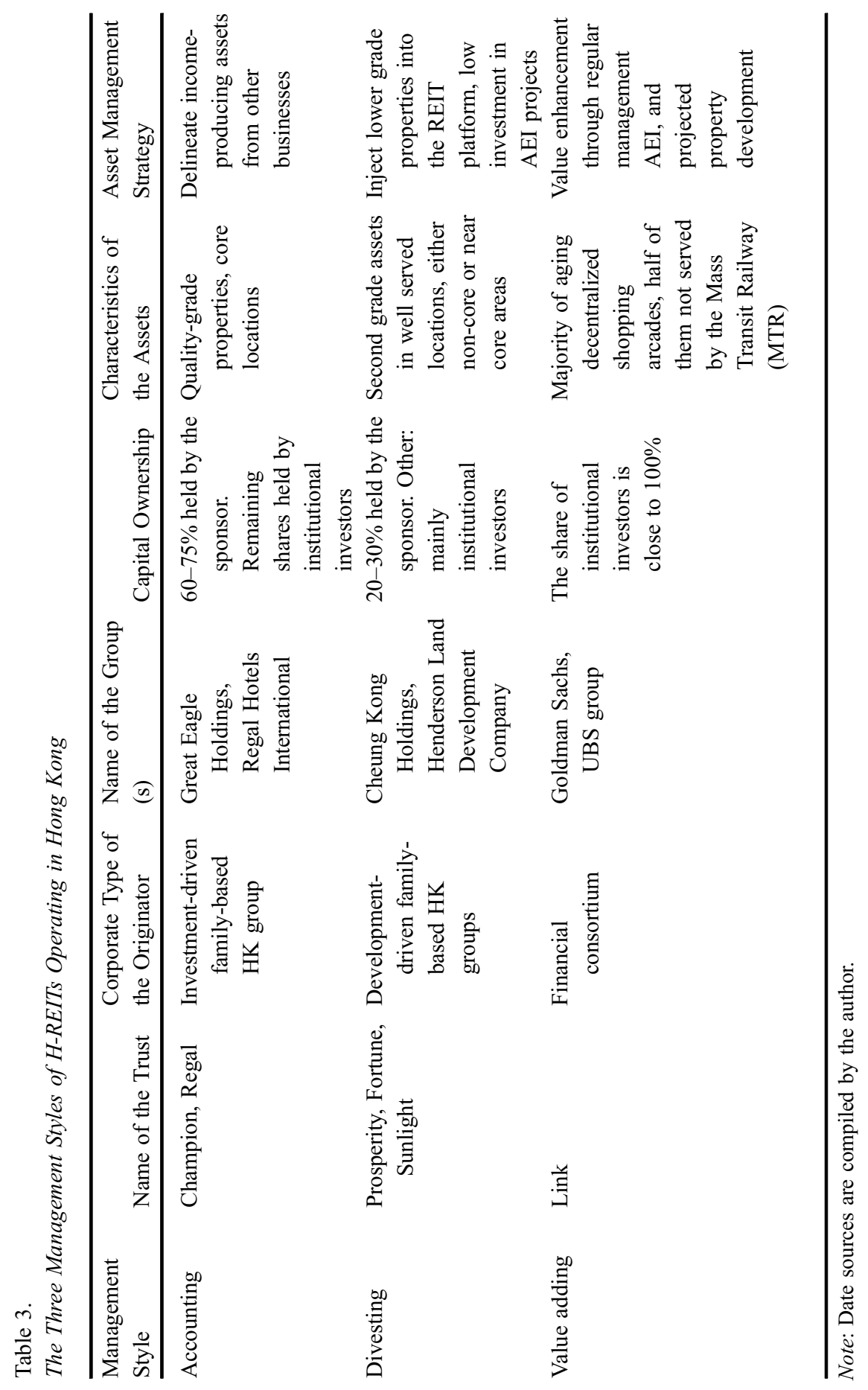


refurbishment and the installation of cost-effective facilities, but there has been no considerable enhancement initiative. Fortune REIT, which is also listed in Singapore, has nevertheless invested a larger amount of capital in asset enhancement than its peers. In the case of Prosperity REIT, stakeholders are enjoying an increase in value without the need for substantial refurbishment work, thanks to the ongoing transformation of East Kowloon into a major sub-core center.

These two types of management styles show strong points of convergence. REIT structures are used by developers merely as platforms to offload assets, either to differentiate high-grade income producing properties from other businesses whilst keeping the major part of the capital (first category), or to recycle capital through the disposal of second grade assets (second category). In neither case has the outsourcing of the properties involved significant asset enhancement or expansion of the portfolios. Another similarity between these trusts is their use of financial engineering to boost their yields for the first few years after their listing. Prosperity, Champion, Sunlight and Regal REITs all set up yield enhancement arrangements at the time of their IPO to artificially create higher distribution for prospective investors (Newell \& Sieracki, 2009, p. 74). Such measures were implemented to allow the sponsor groups to maximize the selling price of their properties. Since then the financial engineering arrangements have expired, but the yields provided by these trusts still compare favorably with the returns on local government bonds (Newell, 2012).

The use of REITs as platforms to outsource lower grade properties is in strong contrast to the commitment of Singaporean family-based or government-based groups to expand portfolios of quality assets. In Singapore, 19 landmark office towers were held by local REITs in 2012 (Masumiya, 2012, p. 5) as opposed to four A-grade buildings in Hong Kong (currently five). The reluctance of Hong Kong groups to spin off quality-grade assets can be explained by a "tendency for family perpetuity as regards company ownership" (Poon, 2010, p. 27) against a backdrop of continuous increase in real estate values in the long run. As stated by a representative of the Core Pacific-Yamaichi group,

In Hong Kong, you can create an incredible value from real estate. So if you are a grandson or the son of a real estate father or grandfather, selling these assets is a pretty big decision because of the value creation that has happened [...] that's why there aren't a lot of REIT activities because of the value expectation. ${ }^{8}$

Standing out as an exception, the Cheung Kong Group's active REIT sponsoring may be attributed to the enormous wealth and subsequent power resources of the

\footnotetext{
${ }^{8}$ South China Morning Post, January 14, 2014.
} 
funder. In 2015, Sir Ka-shing Li ranked 14th on the Forbes List of world fortunes and first in Asia. Owing to his core cash flows from ports, retail, electricity and other quasimonopolistic businesses in Hong Kong, he is in a better position than his peers to venture into random diversification (Studwell, 2008). This ability also provides him with an outstanding advantage for bargaining with the Chinese authorities to capture opportunities for property development in the Mainland and obtain permission to spin off China-based assets onto H-REIT structures. It is worth noting that the underlying assets of Cheung Kong-sponsored REITs are of much better quality in China than in Hong Kong - thus ensuring more sustainable returns in the long run — but they are significantly less liquid, given their size and the stringent rules governing transactions on the Mainland.

\section{Aggressive Value-Addition Management Style by the Link}

In contrast to the two previous categories of trusts, the Link REIT is entirely focused on the value enhancement of its portfolio. With $100 \%$ of its capital held by investors, this trust is governed by the objective of maximizing shareholder value and returns, in line with the US-conceived model. The Link's underlying assets were acquired in 2006 at HK\$22 billion through an en bloc sale to the HKHA, with a discount of HK\$8 billion on the price set before the legal challenge. ${ }^{9}$ Currently holding 175 properties, the trust is Hong Kong's biggest retail property and car park facility owner, capturing $11 \%$ and $16 \%$ of the retail and car parking markets respectively. Its portfolio mainly consists of (initially) low-grade decentralized shopping arcades, including 98 properties in the New Territories, 63 in Kowloon and 14 on Hong Kong Island (Figure 2). Half of the assets are small neighborhood centers in poorly served areas, where local residents find essential commodities. The other half consists of shopping arcades well served by the Mass Transit Railway (MTR), providing a broader range of foods, beverages and entertainment. To achieve substantial growth in its portfolio, the Link combines three key strategies: asset management, asset enhancement and asset investment.

The asset management of the portfolio involves the installation of reception desks and new lighting in all retail premises, combined with cost-efficient cleaning and security services. Following alliances with big distribution chains, supermarkets were built in a large number of premises, to the detriment of small vendors who struggle to maintain their businesses with the support of loyal customers. To allow for a rapid

\footnotetext{
${ }^{9}$ South China Morning Post, June 13, 2014.
} 


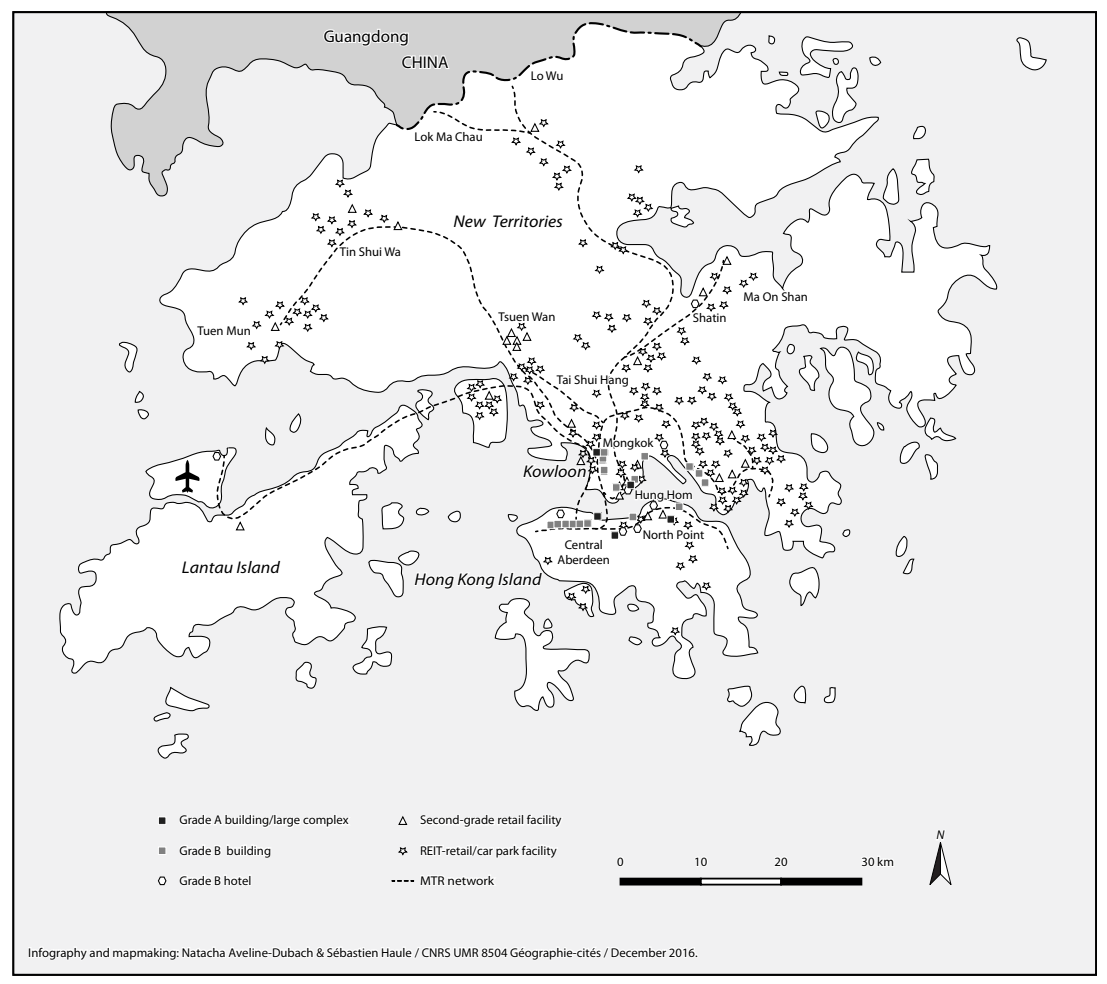

Figure 2. Spatial distribution of the H-REIT property portfolios.

Sources: The author and Géographie-cités.

growth in yields, the terms of the leases were shortened from 4-5 years to 2-3 years, and rents have increased by $25-30 \%$ at each renewal period. In the wet markets, ${ }^{10}$ the shopkeepers are urged to improve their practices in order to attract a non-residential clientele; they can benefit from a lower increase in rent if they agree to keep their stand clean, not spit or throw cigarette butts on the ground and stop betting in the workplace.

The situation differs in retail premises that are subject to an "Asset Enhancement Initiative" (AEI), because only a few shopkeepers can remain on site. The Link's strategy is to carry out three AEIs per year. Between 2005 and 2016, 41 retail facilities were fully refurbished. The objective of an AEI is to increase the catchment area of retail facilities by drastically transforming their tenant-mix through the establishment of big retail chains. As a result, rents in these places have increased considerably.

\footnotetext{
${ }^{10}$ The wet market is a traditional market in Hong Kong where meat, fish and vegetables are sold. The Link holds about 80 wet markets.
} 
In March 2013, the average monthly unit rent per square meter was HK\$55.7 for the 10 top Link properties, as opposed to HK\$38.4 on average for the portfolio overall. It is noteworthy that the rent by square meter of franchise outlets and supermarkets is lower than that for individual tenants. This is justified on the grounds that large chain stores attract a broader customer base and hence upscale the retail business in the housing estates (Chung \& Ngai, 2007).

In parallel to AEIs, the Link accrued recycled capital from its portfolio by selling nine decentralized properties. The tenders attracted interest from numerous potential buyers so that the properties were sold at $30 \%$ above their appraised value. This allowed the Link to gain a foothold in Mainland China in 2015 with the acquisition of two large retail properties in Beijing and Shanghai. The trust has also recently engaged in property development, as permitted under the newly amended H-REIT legislation. It has established a joint venture with a developer (Nan Fung Development) to construct an A-grade building in the future central business district (CBD) of Kowloon East, expected to be completed in 2020 .

As a result of these strategies, the Link has recorded its best performance by far in the H-REIT market, with an increase in value of each share from HK\$10 to HK\$40 since the IPO. One might therefore wonder what kind of investors have benefited from such a strong performance.

The divide between institutional investment and small (retail) investment in the composition of Link's capital has actually recorded significant change over time. Initially, the government planned to dedicate a mere $10 \%$ of the Link's shares to small investors, although it had marketed the securitization of HKHA's assets as "a way to return the wealth to the people." However, due to the tremendous demand for investment by upper-middle class households, the government reallocated the "retail portion" (for small investors) from $10 \%$ to $50 \% .{ }^{11}$ When the IPO was challenged in the courts in 2005, individual investors responded by demonstrating on the streets, accusing anti-Link activists of "stopping them from becoming prosperous." 12 After the court ruled in favor of the Link, the IPO was relaunched but the retail portion was reduced to $30 \%$. Since then, no information on the Link's capital structure has been given to the public, despite the REIT's constant assertion of its high standard of transparency. Some shares are owned by local charities and by education and pension funds, prompting the Link manager to claim that "the elderly, the young and those in

\footnotetext{
${ }^{11}$ Accessed on April 2016 from < http://www.tax-news.com/news/Link_REIT_IPO_Secures_HK100_ Billion_In_Retail_Orders_21826.html $>$.

${ }^{12}$ Oriental Daily, May 2, 2005.
} 
need can benefit from our growth and distribution of returns." ${ }^{\prime 3}$ This statement belies the fact, however, that Hong Kong's households no longer have access to the Link's rewarding returns, since the overwhelming portion of the trust's capital - if not the totality - is held by institutional investors.

Due to the substantial value creation it involves, this management style is having a significant socio-economic impact on the social housing estates, where rent increases for retail premises are driving up the cost of daily commodities for residents, a fifth of whom live on welfare payments (US\$460/month ${ }^{14}$ ). The aging of the residents makes the situation more acute because of the low level of pensions. Older people already account for $30 \%$ of the residents in many housing estates (Chiu, 2010). Such issues are particularly well illustrated in the case of Lok Fu Plaza, where the Link conducted an AEI during the years 1983-2013.

\section{Socio-Economic Outcomes of the Value Creation Policy in Lok Fu Plaza}

Situated in East Kowloon, next to an MTR station, the Lok Fu housing estate accommodates 42,200 residents, of which $28 \%$ are over 60 years old. ${ }^{15}$ The renovation of the Lok Fu Plaza shopping center is the largest AEI project conducted by the Link, involving a gross floor area of 38,000 square meters. The Link invested HK\$429 million in the refurbishment project of the shopping mall during the years 1983-1991, and a further HK\$120 million to modernize the wet market in 2013. The total amount represents approximately two times the average cost of other AEIs conducted by the Link. ${ }^{16}$ Considering the size of both the facility and the financial investment, Lok Fu Plaza can be considered a relevant case study for analyzing the impacts of the Link's AEI policy.

Similar to other public housing complexes run by the HKHA, the Lok Fu estate had a commercial space with partly subsidized commercial rents, to ensure cheap daily products for low-wage residents of the estates. Many small store tenants were not much better off financially than the residents, hence cheap rents were important for the survival of their businesses. Following the renovation of the shopping mall, the tenant mix was radically modified to the benefit of supermarkets and franchises. While three

\footnotetext{
${ }^{13}$ See $<$ http://www.linkreit.com/ENText/Pages/FAQs.aspx $>$.

${ }^{14}$ According to a survey carried out on a sample of 16,000 HKHA tenants and reported in the daily China Morning Post of May 22, 2012.

${ }^{15}$ HKHA data (accessed on March 31, 2011).

${ }^{16}$ If we consider the two malls near Wong Tai Sin station separately, and also the ones in Kowloon ("Temple Mall North" and "Temple Mall South"), the consolidated cost of the AEIs is HK\$656 for a total surface of 26,750 sqm.
} 
tenants were allowed to remain in the front arcade due to the unique quality of their products (glass art, speciality teas, wools), they have seen a $200 \%$ increase in their rents since the renovation, and their continued presence in the mall is the subject of tough negotiation every time the lease is renewed. Twenty former tenants of shops selling more ordinary items have also been allowed to remain on the site, but have been relegated to a dedicated space named the "Lok Fu Bazaar" situated towards the rear of the arcade. Their rents are lower than those in the front arcade, but the facilities have little visibility within the shopping area.

Despite these difficult conditions, the shopkeepers who had managed to stay in the arcade could not publicly express dissatisfaction with the AEI project. The situation was different for their peers in the wet market. Shortly after privatization, the stalls experienced an increase of $25-30 \%$ at each contract renewal, which in turn forced the shopkeepers to increase the prices of their products. Observing the defection of their clientele, they started to engage in a protest against the rent increases. In 2007 , Lok Fu Plaza became the focal point of a large-scale demonstration, gathering 3,000 tenants from 30 Link housing estates. The protestors smashed rice bowls at the entrance of the shopping arcade and tore into pieces a giant check representing the annual income of the Link's CEO. In doing so, the shopkeepers hoped to demonstrate an ability to influence Link's share values by attracting the attention of the media. Yet the demonstration received only moderate coverage from the press and did not influence the stock markets. In response, the Link affected a more conciliatory attitude but its only move was the designation of a new CEO. Thereafter the small vendors of Lok Fu Plaza became extremely fatalistic. When the wetmarket went through an AEI in 2013, they did not take any action, despite the fact that the renovation would put a large number of them out of business.

Through the AEI, the Link has improved the layout and hygiene of the retail premises. It has created a new environment that attracts new retailers and addresses the changing needs of customers. As a result, the catchment area of the Lok Fu Plaza shopping mall has been substantially enlarged to lure the financially comfortable households of adjacent neighborhoods. Yet the picture is different for the elderly residents of the housing estates, who have unanimously expressed strong dissatisfaction with the renovation. They do not feel welcome in facilities that have been designed for young customers and have limited seating areas. Their basic food supplies can only be bought from the fresh market, since the food court of the shopping arcade is way above their means. Yet the prices of food in the fresh market too have soared since privatization. Around one third of the residents interviewed takes the bus to the less expensive fresh markets in Kowloon. The oldest residents, however, can no 
longer travel and must therefore resign themselves to an erosion in their purchasing power and to dependence on family. Thus it is clear that the securitization of the HKHA's assets is having a severe negative effect on the most vulnerable residents, who will grow in number as the population ages in Hong Kong.

\section{Conclusion}

The present study has used the case of Hong Kong to reflect on the urban and social dynamics generated by the circulation of finance capital within the "real estate securitized channel." It supports previous findings that a proactive mediation by property developers and a strong state involvement are prerequisites for the development of financial instruments rooted in the urban fabric. The results are also consistent with the growing recognition that the financialization of the built environment tends to exacerbate social polarization and to trigger political conflicts (Fields \& Uffer, 2016; Gotham, 2009). Yet, this observation must be weighed against the contingent conditions in which real estate securitization take place.

As evidenced by the H-REIT experience, the urban dynamics of liquid capital displays patterns that are quite varied, according to the corporate environment and asset management objectives of the initiator/sponsor groups. Hong Kong's traditional property groups were expected to develop large-size REIT portfolios, both domestically and in China, just as their Singaporean counterparts did. However, due to a family-based corporate environment characterized by a strong reluctance to divest quality-grade assets, the securitization of properties has not been very active. These groups have established REITs either for accounting purposes or to divest decentralized lower-grade properties. In both cases, the management styles have not been conducive to new urban dynamics because of the limited growth and value enhancement of the portfolios.

A sharp contrast is seen in the management style of the Link REIT, however. Driven by a "shareholder value" corporate governance, the Link has pursued a very active policy of value enhancement of its property portfolio, providing by far the highest yields amongst H-REIT investment vehicles. The potential for value creation offered by below-market welfare retail facilities was further increased by the conditions of an "en bloc" sale that was discounted further after the legal challenge. The Link was additionally allowed to perform a "dynamic" management of its assets, through the disposal of less desirable properties, although such strategies violate the commitment to maintain cheap means of subsistence for social housing residents. 
As a result of the value-addition management style developed by the Link, big retail chains targeting younger and more affluent customers from outside the social housing estates, have replaced a large proportion of the tenants of the welfare retail facilities. This has generated a disparity in the consumption patterns of daily necessities in the housing estates - pulling in young wealthy customers and pushing out low-income residents. In particular, aged residents are being excluded from the benefits of the improved shopping environment. Those who can no longer afford to buy necessities in the renovated commercial space must commute to other districts to look for cheaper products. Thus, the securitization process has disintegrated the spatial integrity of the housing estates by destroying the historical link between residential and commercial welfare spaces (Chung \& Ngai, 2007). It has introduced a de-contextualization (Savini \& Aalbers, 2016) of decisions regarding the management of retail facilities that is likely to worsen as the divesting of less desirable properties continues.

From a political perspective, privatizing the HKHA's properties using securitization techniques proved to be the best way to avoid major conflict, since a REIT as a "public" platform is theoretically accessible to any kind of investor. This was facilitated by the unique combination of investor-friendly regulations (including very flexible leasing contracts) and weak political accountability that characterizes the Hong Kong Special Administrative Region. With the proceeds of the sale of public assets, the government was able to avoid injecting further capital into the public housing sector for several years (Chiu, 2010), and at the same time enhance Hong Kong's competitiveness as a global financial center through new lines of rewarding vehicles for institutional investment. Yet government action has encountered fierce opposition from anti-Link protesters. Despite the support of some policy makers and the extension of anti-Link protests against a wide range of urban stakeholders, the Link's value-addition management style has not been challenged in any way. Even the attempt by shopkeepers to turn liquidity — the distinctive feature of REITs - to their advantage through symbolic public gestures made no impact on the share value of the Link. This experience takes on a special resonance at a time when China, a country that also has a rapidly aging population, is considering experimenting with property securitization and transferring part of the social housing pool to REIT-like structures.

This paper represents a preliminary attempt at delineating the distinctive urban and social dynamics set in motion by the "securitized" (property) investment channel. Further empirical work on REIT management style is needed in other city-regions to improve our understanding of the way liquid capital anchors into local real estate markets. 


\section{Acknowledgment}

This research was supported by a Grant from the French National Research Agency (ANR FINURBASIE, ANR-12-BSH1-0014), and residence allowances in Hong Kong provided by the French National Research Center (CNRS).

\section{References}

Aglietta, M. (2008). New trends in corporate governance: The prominent role of the long run investor. Competition \& Change, 12(2), 203-222.

Asia Pacific Real Estate Association (APREA). (2014). The increasing importance of real estate in Asian pension funds. Singapore: APREA editions.

Atchison, K., \& Yeung, V. S. (2014). The impact of REITs on Asian economies, Singapore. Asia Pacific Real Estate Association (APREA). Retrieved from http://www.aprea.asia/file/ The\%20Impact $\% 20$ of\%20REITs\%20on\%20Asian\%20Economies.pdf.

Attuyer, K., Guironnet, A., \& Halbert, L. (2012). Turning pumpkins into carriages: Sustainable urban development and the financialization of "green" commercial real estate in France. Articulo-Journal of Urban Research, 2012(9), 1-20.

Aveline-Dubach, N. (2014). New patterns of property investment in "post-bubble" Tokyo: The shift from land to real estate as a financial asset. In N. Aveline-Dubach, S. C. Jou, \& M. Hsiao (Eds.), Globalization and new intra-urban dynamics in Asian cities (pp. 265-294). Taipei, Taiwan: National Taiwan University Press.

Aveline-Dubach, N. (forthcoming). Centralité du foncier dans le régíme d'accumulation du capital en Chine [centrality of land in the accumulation regime of capital in China], Revue La Régulation.

Baum, A. E., \& Hartzell, D. (2012). Global Property Investment: Strategies, Structures, Decisions. Oxford, England: Wiley-Blackwell.

Boisnier, C. (2015). Les Sociétés Foncières: Entre Finance et Ville Durable [Property companies: Between finance and urban sustainability]. Paris, France: Editions l'Harmattan.

Boyer, R. (2000). Is a finance-led growth regime a viable alternative to Fordism? A preliminary analysis. Economy and Society, 29(1), 111-145.

Brenner, N., \& Theodore, N. (2002). Cities and the geographies of "actually existing neoliberalism." Antipode, 34(3), 349-379.

Brenner, N., \& Theodore, N. (2005). Neoliberalism and the urban condition. City, 9(1), 101-107.

Capozza, D. R., \& Seguin, P. J. (2000). Debt agency, and management contracts in REITs: The external advisor puzzle. The Journal of Real Estate Finance and Economics, 20(2), 91-116. 
Chan, C. K. (2003). Protecting the ageing poor or strengthening the market economy: The case of the Hong Kong Mandatory Provident Fund. International Journal of Social Welfare, $12(2), 123-131$.

Chiu, R. L. (2007). Planning, land and affordable housing in Hong Kong. Housing Studies, 22(1), 63-81.

Chiu, R. L. (2010). The transferability of Hong Kong's public housing policy. European Journal of Housing Policy, 10(3), 301-323.

Chiu, S., \& Lui, T. L. (2009). Hong Kong: Becoming a Chinese global city. London, England: Routledge.

Chow, K. M. (2011). An analysis of Hong Kong REIT: Current and future opportunities for investors (Master's thesis). Massachusetts Institute of Technology.

Chow, N. (1998). The making of social policy in Hong Kong: Social welfare development in the 1980s and 1990s. In R. Goodman, G. White, \& H.-J. Kwon (Eds.), The East Asian welfare model: Welfare orientalism and the state (pp. 159-174). London, England: Routledge.

Chung, C. Y., \& Ngai, P. (2007). Neoliberalization and privatization in Hong Kong after the 1997 financial crisis. China Review, 7(2), 65-92.

Claessens, S., Djankov, S., \& Lang, L. H. (2000). The separation of ownership and control in East Asian corporations. Journal of Financial Economics, 58(1-2), 81-112.

Clark, G. L. (2000). The functional and spatial structure of the investment management industry. Geoforum, 31(1), 71-86.

Coakley, J. (1994). The integration of property and financial markets. Environment and Planning A, 26(5), 697-713.

Corpataux, J., \& Crevoisier, O. (2005). Increased capital mobility/liquidity and its repercussions at regional level some lessons from the experiences of Switzerland and the United Kingdom (1975-2000). European Urban and Regional Studies, 12(4), 315-334.

Cushman \& Wakefield. (2016). The great wall of money 2016. Retrieved from http://www. cushmanwakefield.com/ /media/global-reports/Great_Wall_of_Money_2016.pdf.

David, L., \& Halbert, L. (2014). Finance capital, actor-network theory and the struggle over calculative agencies in the business property markets of Mexico City Metropolitan Region. Regional Studies, 48(3), 516-529.

Dixon, A. D., \& Monk, A. H. (2009). The power of finance: Accounting harmonization's effect on pension provision. Journal of Economic Geography, 9(5), 619-639.

Engelen, E. (2003). The logic of funding European pension restructuring and the dangers of financialisation. Environment and Planning A, 35(8), 1357-1372.

EY Global Real Estate. (2016). Global perspectives: 2016 REIT report. Retrieved from http:// www.ey.com/Publication/vwLUAssets/ey-global-perspectives-2016-reit-report/\$FILE/ ey-global-perspectives-2016-reit-report.pdf. 
Falzon, R., Halle, M., \& McLemore, R. (2003). Private equity investment opportunities in real estate. Journal of Private Equity, 6(2), 68-78.

Fields, D. (2015). Contesting the financialization of urban space: Community organizations and the struggle to preserve affordable rental housing in New York City. Journal of Urban Affairs, 37(2), 144-165.

Fields, D., \& Uffer, S. (2016). The financialisation of rental housing: A comparative analysis of New York City and Berlin. Urban Studies, 53(7), 1486-1502. (First published online 2014).

French, S., Leyshon, A., \& Wainwright, T. (2011). Financializing space, spacing financialization. Progress in Human Geography, 35(6), 798-819.

Froud, J., Haslam, C., Johal, S., \& Williams, K. (2002). Financialisation and the coupon pool. Capital \& Class, 26(3), 119-151.

Gotham, K. F. (2009). Creating liquidity out of spatial fixity: The secondary circuit of capital and the subprime mortgage crisis. International Journal of Urban and Regional Research, 33(2), 355-371.

Guironnet, A., Attuyer, K., \& Halbert, L. (2016). Building cities on financial assets: The financialisation of property markets and its implications for city governments in the Paris city-region. Urban Studies, 53(7), 1442-1464.

Halbert, L., \& Attuyer, K (2016). Introduction: The financialisation of urban production: Conditions, mediations and transformations. Urban Studies, 53(7), 1347-1361.

Halbert, L., \& Rouanet, H. (2014). Filtering risk away: Global finance capital, transcalar territorial networks and the (un) making of city-regions: An analysis of business property development in Bangalore, India. Regional Studies, 48(3), 471-484.

Heung, A. L. M., \& Zweig, D. (2011). Hong Kong's contribution to Mainland China's property sector. Asian Survey, 51(4), 739-768.

Kendall, L. T., \& Fishman, M. J. (2000). A Primer on Securitization. Cambridge, MA: MIT Press.

Keogh, G. (1994). Use and investment markets in British real estate. Journal of Property Valuation and Investment, 12(4), 58-72.

Lai, K. (2012). Differentiated markets: Shanghai, Beijing and Hong Kong in China's financial centre network. Urban Studies, 49(6), 1275-1296.

Langley, P. (2007). Everyday investor subjects and global financial change: The rise of AngloAmerican mass investment. In J. M. Hobson \& L. Seabrooke (Eds.), Everyday politics of the world economy (pp. 103-119). Cambridge, NY: Cambridge University Press.

Le Galès, P. (2000). Private-sector interests and urban governance. In A. Bragnasco \& P. Le Galès (Eds.), Cities in contemporary Europe (pp. 178-197). Cambridge, England: Cambridge University Press. 
Lee, E. W. (2005). The renegotiation of the social pact in Hong Kong: Economic globalisation, socio-economic change, and local politics. Journal of Social Policy, 34(2), 293-310.

Lizieri, C., \& Finlay, L. (1995). International property portfolio strategies: Problems and opportunities. Journal of Property Valuation and Investment, 13(1), 6-21.

Markowitz, H. (1952). Portfolio selection. The Journal of Finance, 7(1), 77-91.

Martin, R. (2002). Financialization of Daily Life. Philadelphia, PA: Temple University Press.

Masumiya, M. (2012). S-REIT from the Viewpoint of Overseas Investors. Tokyo, Japan: NLI Research Institute.

Meyer, D. R. (2000). Hong Kong as a Global Metropolis. Cambridge, England: Cambridge University Press.

Newell, G. (2011). The Benefits of an Allocation to Asian Real Estate for Institutional Investors. Singapore: APREA.

Newell, G. (2012). The Investment Characteristics and Benefits of Asian REITs for Retail Investors. Singapore: APREA.

Newell, G., \& Sieracki, K. (2009). Global Trends in Real Estate Finance. Singapore: WileyBlackwell.

Newell, G., \& Worzala, E. (1995). The role of international property in investment portfolios. Journal of Property Finance, 6(1), 55-63.

Newell, G., Wu, Y., Chau, K. W., \& Wong, S. K. (2010). The development and performance of REITs in Hong Kong. Pacific Rim Property Research Journal, 16(2), 190-206.

Newman, K. (2009). Post-industrial widgets: Capital flows and the production of the urban. International Journal of Urban and Regional Research, 33(2), 314-331.

Ng, C. Y. (2005). An empirical study on the relationship between ownership and performance in a family-based corporate environment. Journal of Accounting, Auditing \& Finance, 20(2), 121-146.

Ooi, J. T., \& Har, N. P. (2009). Asia REIT, playing the yield's game. In G. Newell \& K. Sieracki (Eds.), Global trends in real estate finance (pp. 64-81). Singapore: Wiley-Blackwell.

Ooi, J. T., Ong, S.-E., \& Neo, P.-H. (2011). The wealth effects of property acquisitions: Evidence from Japanese and Singaporean REITs. Real Estate Economics, 39(3), $487-505$.

Pica, A. (2011). Asia-Pacific REITs, building REITs through better governance. CFA Institute, Asia Pacific Office. Retrieved from http://www.cfapubs.org/doi/pdf/10.2469/ccb.v2011. $\mathrm{n} 4.1$.

Pierson, P. (2002). Welfare state restructuring in affluent democracies. Revue Française de Sociologie, 43(2), 369-405.

Poon, A. (2010). Land and the Ruling Class in Hong Kong. Singapore: Enrich Professional Publishing. 
Sassen, S. (2002). Global Networks, Linked Cities. London, England: Routledge.

Savini, F., \& Aalbers, M. B. (2016). The de-contextualisation of land use planning through financialisation: Urban redevelopment in Milan. European Urban and Regional Studies, 23(4), 878-894.

Sirmans, C. F., \& Worzala, E. (2003). International direct real estate investment: A review of the literature. Urban Studies, 40(5-6), 1081-1114.

Solnik, B. H., \& McLeavey, D. W. (1991). International Investments. Reading, MA: AddisonWesley.

Sotelo, R., \& McGreal, S. (2013). Real Estate Investment Trusts in Europe: Evolution, Regulation, and Opportunities for Growth. Berlin, Germany: Springer Science \& Business Media.

Studwell, J. (2008). Asian Godfathers: Money and Power in Hong Kong and South-East Asia. London, England: Profile Books.

Swyngedouw, E. (2004). Globalisation or "glocalisation"? Networks, territories and rescaling. Cambridge Review of International Affairs, 17(1), 25-48.

Theodore, N., Peck, J., \& Brenner, N. (2011). Neoliberal urbanism: Cities and the rule of markets. In G. Bridge \& S. Watson (Eds.), The new Blackwell companion to the City (pp. 15-25). West Sussex, England: Wiley-Blackwell.

Theurillat, T., Corpataux, J., \& Crevoisier, O. (2010). Property sector financialization: The case of Swiss pension funds (1992-2005). European Planning Studies, 18(2), 189-212.

Theurillat, T., \& Crevoisier, O. (2013). The sustainability of a financialized urban megaproject: The case of Sihlcity in Zurich. International Journal of Urban and Regional Research, 37(6), 2052-2073.

Wainwright, T. (2009). Laying the foundations for a crisis: Mapping the historico-geographical construction of residential mortgage backed securitization in the UK. International Journal of Urban and Regional Research, 33(2), 372-388.

Wechsler, S. A. (2013). The role of REITs in strategic investment portfolios. In R. Sotelo \& S. McGreal (Eds.), Real estate investment trusts in Europe (pp. 43-52). Berlin, Germany: Springer.

Wood, A. (2004). The scalar transformation of the US commercial property-development industry: A cautionary note on the limits of globalization. Economic Geography, 80(2), 119-140.

Zhao, S. X., Lao, Q., \& Neo, Y. M. C. (2013). The rise of China and the development of financial centres in Hong Kong, Beijing, Shanghai, and Shenzhen. Journal of Globalization Studies, 4(1), 32-62. 